\title{
USING NEW Rf INBRED LINES ORIGINATING FROM AN INTERSPECIFIC POPULATION WITH H. deserticola FOR DEVELOPMENT OF SUNFLOWER HYBRIDS RESISTANT TO BROOMRAPE
}

\author{
Hladni, N. ${ }^{*}{ }^{\text {, Jocić, }}$ S. ${ }^{1}$, Miklič, V. $^{1}$, Saftić-Panković, D. ${ }^{1}$, Škorić, D. $^{2}$ \\ ${ }^{1}$ Institute of Field and Vegetable Crops, Maksima Gorkog 30, \\ 21000 Novi Sad, Republic of Serbia \\ ${ }^{2}$ Serbian Academy of Sciences and Arts, Novi Sad Branch, Nikole Pašića 6, \\ 21000 Novi Sad, Republic of Serbia
}

Received: July 15, 2009

Accepted: November 10, 2009

\section{SUMMARY}

One of the directions in sunflower breeding is the selection for resistance to broomrape. The population of broomrape has been stable in Serbia for a long period of time, but the racial composition has changed in recent years, with race $\mathrm{E}$ being predominant in the regions of north Bačka and Banat. Cultivated sunflower is genetically narrow and deficient in many desirable genes. Its genetic variability can be increased by the use of wild sunflower species and interspecific hybridization.

The resistance to broomrape in 15 new experimental hybrids was tested on locations in Serbia (Pačir) during three years (2006, 2007 and 2008) and in Romania (Baragan, Braila) during 2008. These hybrids were produced by crossing female inbred lines (Ha-26PR-A, $\mathrm{PH}-\mathrm{BC}_{2}-92-\mathrm{A}$ and Ha-98-A) susceptible to broomrape race $\mathrm{E}$ and new $R f$ inbred lines (RHA-D-2, RHA-D-5, RHA-D6, RHA-D-7, RHA-D-8), developed from interspecific populations originating from $H$. deserticola and resistant to race $\mathrm{E}$. All examined hybrids were resistant to broomrape in both locations. Since broomrape race $F$ is present in the location in Romania, it is expected that the new $R f$ inbred lines - male components of the examined hybrids, possess the resistance gene for race $\mathrm{F}$ also.

Key words: sunflower, interspecific hybridization, resistance, broomrape

\section{INTRODUCTION}

The broomrape (Orobanche cumana Wallr) is currently regarded as one of the most important constraints in sunflower (Helianthus annuus L.) production (Fernandez-Martinez et al., 2008). The broomrape is an important parasitic angiosperm

* Corresponding author: Phone: +381214898 411; Fax: +381216413 833;

e-mail: nadah@ifvcns.ns.ac.rs 
totally devoid of chlorophyll, which infects the roots of sunflower plants in warm and dry regions (Ruso et al., 1996). It can significantly reduce seed and oil yields, 1000-seed weight, seed oil content, plant height and head diameter of sunflowers (Kaya et al., 2004).

The sunflower plant attacked by broomrape and the seed produced by it suffer serious morphological and biochemical changes, which are directly associated with the intensity of parasite attack (Shindrova et al., 1998). These attacks are frequently so severe that they diminish the yield up to 50\% (Dominguez et al., 1996).

The broomrape is an important limiting factor in sunflower production, especially in countries adjacent to the Black Sea as well as in Spain, Israel, Serbia, China and several other countries. It is, therefore, necessary not just to develop a highly productive hybrid but to determine genes for resistance to broomrape as well (Škorić et al., 2007). The resistance to broomrape races is controlled by single dominant $O r$ genes. As the sunflower acreage in the world increased, new broomrape races have developed. Until few years ago, only 5 physiological races (A, B, C, $\mathrm{D}$ and $\mathrm{E}$ ) existed among the sunflower broomrape populations and five sunflower dominant genes $\left(\mathrm{Or}_{1}, \mathrm{Or}_{2}, \mathrm{Or}_{3}, \mathrm{Or}_{4}\right.$ and $\left.\mathrm{Or}_{5}\right)$ conferring the resistance towards these broomrape races were known. A sudden change in race composition has recently occurred. A new race, called race $\mathrm{F}$, has occurred in Romania, Bulgaria, Spain and Turkey. The new broomrape race cannot be controlled by $\mathrm{Or}_{5}$ gene. The changes in the broomrape population and the occurrence of the new race are new challenges for sunflower breeding, forcing the breeders to continually test the breeding material against new broomrape races while creating differential lines.

The broomrape population in Serbia was stable for a long period of time. The dominant broomrape race was race $\mathrm{B}$ and all hybrids were genetically resistant to it. Broomrapes started to significantly endanger the sunflower production since 1995, when a change in race composition was observed on sunflowers grown on lighter soil types in the north of Bačka and Banat, the Vojvodina Province. A detailed research showed that we were dealing with a new race, race $\mathrm{E}$ (Mihaljčević, 1994). Race E has expanded through the Bačka and Banat regions, slowly becoming a serious problem in the sunflower production. The sunflower breeding program at Institute of Field and Vegetable Crops (IFVC) has been directed towards creating lines and hybrids which resistant to new broomrape races. The screening for resistance to race $\mathrm{E}$ was conducted in broomrape-infested fields, first in the area around Bačka Topola and Svetozar Miletić, and then it was continued in the field near Pačir.

Cultivated sunflower is genetically narrow and deficient in many desirable genes but there is a large number of wild relatives of the genus Helianthus which have provided a continued source of desirable agronomic traits (Seiler and Rieseberg, 1997; Seiler, 1992; Seiler and Brothers, 2003).

Interspecific hybridization was applied in sunflower breeding for the resistance to broomrape. This process involves first the discovery of desirable genes in wild 
Helianthus species and then their incorporation into cultivated sunflower genotypes. In this investigation, several interspecific populations with $H$. deserticola had been initially used with the intention to make $R f$ male inbred lines resistant to drought. Namely, $H$. deserticola is an annual wild species adapted to desert environments. Several agronomically important traits of new $R f$ inbred lines and their hybrids were evaluated and are discussed in this paper. Unexpectedly, resistance to broomrape race $\mathrm{E}$ was observed and it was consistent in all examined locations in Serbia (Pačir) during three years $(2006,2007,2008)$ and in Romania (Baragan, Braila) during 2008. This indicated that some interspeciefic populations with $H$. deserticola were resistant to broomrape and could be used for the production of new resistant sunflower hybrids.

\section{MATERIAL AND METHOD}

New $R f$ inbred lines (RHA-D-2, RHA-D-5, RHA-D-6, RHA-D-7, RHA-D-8) were produced at IFVC from interspecific populations originating from $\mathrm{H}$. deserticola. Initially the plants were selected from the interspecific population DES-1474-1, 2, 3 originating from $H$. deserticola and subjected to inbreeding. The testing of the material to broomrape resistance was conducted in a greenhouse and in an infested field. The greenhouse testing included the sowing of sunflower plants in test tubes filled with a mixture of sand, earth and perlite into which broomrape seeds were added. This method allows to test a large number of genotypes on a small area and in 4-5 weeks. Testing lines and hybrids in a field infested with broomrape, which was also applied in this study, is a most reliable method of checking broomrape resistance in breeding material.

The inbreeding of selected plants from interspecific populations started in 1995 $\left(\mathrm{S}_{1}\right)$. The first screening of sunflower $R f$ lines for broomrape resistance was done in glasshouse in $1999\left(\mathrm{~S}_{5}\right)$. The seed from resistant plants was tested in infested fields, in the area of Svetozar Miletić and Bačka Topola during $2000\left(\mathrm{~S}_{6}\right)$. Selection of resistant plants was continued in the same area from $2001\left(\mathrm{~S}_{7}\right)$ to $2003\left(\mathrm{~S}_{9}\right)$. The same procedure was repeated in Pačir from $2004\left(\mathrm{~S}_{10}\right)$ to $2008\left(\mathrm{~S}_{14}\right)$, which resulted in the development of 5 resistant restorer inbred lines. In all locations lines were sown in 3 rows ( 12 plants per row), but only the plants in the inside row were evaluated. In order to measure the morpho-physiological traits of resistant lines, an experiment was set at Rimski Šančevi experiment field of IFVC, in a randomized complete block system with three replications during 2004. The basic sample for the analysis of the examined traits contained 30 plants ( 10 plants per replication) sampled from the middle row of each block. The plant height and head diameter were measured $(\mathrm{cm})$ in the field at the stage of physiological maturity. The analysis of oil content in seed was carried out nondestructively in a nuclear magnetic resonance (NMR) analyzer. 
Broomrape resistance of the 15 new experimental hybrids was tested in locations in Serbia (Pačir) during three years (2006, 2007 and 2008) and in Romania (Baragan, Braila) during 2008. These hybrids were made by crossing female inbred

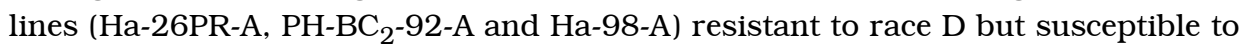
race E, and new $R f$ inbred lines (RHA-D-2, RHA-D-5, RHA-D-6, RHA-D-7, RHA-D-8), developed from interspecific population originating from $\mathrm{H}$. deserticola, and resistant to broomrape race E. Control sunflower genotypes used in Serbia were the line AD66, susceptible to all broomrape races, and the hybrid Bačvanin, resistant to broomrape race $\mathrm{E}$ (it contains the gene $\mathrm{Or}_{5}$ ). The experiment with the hybrids was set up in 2007 in the location of Srbobran, in a randomized complete block system with three replications, with the experimental unit size of $28 \mathrm{~m}^{2}$ (4 rows). The hybrids were evaluated for plant height, head diameter, seed yield, seed oil content and oil yield. The seed yield was calculated on $11 \%$ seed moisture basis. Oil yield was calculated from the seed yield and oil content per plant.

\section{RESULTS AND DISCUSSION}

Breeding of sunflower inbred lines originating from interspecies populations DES-1474-1, DES-1474-2 and DES-1474-3, with the objective of achieving drought tolerance, started in 1994 at IFVC. Apart from the analysis of important agronomic traits, the new restorer lines were tested for resistance to broomrape. The testing of restorer inbred lines was conducted from 1995 to 2004, which resulted in 5 restorer inbred lines derived from interspecific population DES-1474-1, resistant to broomrape race $\mathrm{E}$ (Table1).

Table 1: $R f$ lines resistant to broomrape developed from interspecific populations originating from H. deserticola

\begin{tabular}{lcccccccccc}
\hline Year & 2000 & 2000 & 2001 & 2002 & \multicolumn{2}{c}{2003} & \multicolumn{2}{c}{2004} \\
\cline { 2 - 13 } Location & S.M. & B.T & \multicolumn{2}{c}{ S.M. } & \multicolumn{2}{c}{ S.M. } & \multicolumn{2}{c}{ S.M. } & \multicolumn{2}{c}{ P. } \\
\cline { 2 - 12 } & \multicolumn{2}{c}{$\mathrm{S}_{6}$} & \multicolumn{2}{c}{$\mathrm{S}_{7}$} & \multicolumn{2}{c}{$\mathrm{S}_{8}$} & \multicolumn{2}{c}{$\mathrm{S}_{9}$} & \multicolumn{2}{c}{$\mathrm{S}_{10}$} \\
\hline Origin & $\mathrm{TNI}$ & $\mathrm{RI}$ & $\mathrm{TNI}$ & $\mathrm{RI}$ & $\mathrm{TNI}$ & $\mathrm{RI}$ & $\mathrm{TNI}$ & $\mathrm{RI}$ & $\mathrm{TNI}$ & $\mathrm{RI}$ \\
\hline DES-1474-1 & 326 & 96 & 160 & 25 & 76 & 15 & 45 & 8 & 21 & 5 \\
DES-1474-2 & 96 & 25 & 25 & $/$ & $/$ & $/$ & $/$ & $/$ & $/$ & $/$ \\
\hline
\end{tabular}

S.M.- Svetozar Miletić; B.T.- Bačka Topola; P. - Pačir

$\mathrm{TNI}$ - total number of tested inbred lines; RI - inbred lines resistant to broomrape

The resistance of the new lines was confirmed in the location of Pačir from 2005 to 2008, in tests with two controls: AD66, a line susceptible to all broomrape races, and the hybrid Bačvanin, resistant to broomrape race $\mathrm{E}$ (Table 2).

The new $R f$ lines were also evaluated for plant height, head diameter and seed oil content, and they exhibited significant differences among these characteristics. Plant height ranged from 134 to $173 \mathrm{~cm}$, head diameter from 12.7 to $14 \mathrm{~cm}$ and seed oil content from 40.6 to $49.4 \%$ (Table 3 ). 
Table 2: $R f$ lines resistant to broomrape developed from interspecific populations originating from $H$. deserticola

\begin{tabular}{lllcccc}
\hline \multirow{2}{*}{ Population } & \multirow{2}{*}{ Rf inbred lines } & 2005 & 2006 & 2007 & 2008 \\
\cline { 3 - 6 } & & $\mathrm{S}_{11}$ & $\mathrm{~S}_{12}$ & $\mathrm{~S}_{13}$ & $\mathrm{~S}_{14}$ \\
\hline 1 & DES-1474-1 & RHA-D-2 & $\mathrm{R}$ & $\mathrm{R}$ & $\mathrm{R}$ & $\mathrm{R}$ \\
2 & DES-1474-1 & RHA-D-5 & $\mathrm{R}$ & $\mathrm{R}$ & $\mathrm{R}$ & $\mathrm{R}$ \\
3 & DES-1474-1 & RHA-D-6 & $\mathrm{R}$ & $\mathrm{R}$ & $\mathrm{R}$ & $\mathrm{R}$ \\
4 & DES-1474-1 & RHA-D-7 & $\mathrm{R}$ & $\mathrm{R}$ & $\mathrm{R}$ & $\mathrm{R}$ \\
5 & DES-1474-1 & RHA-D-8 & $\mathrm{R}$ & $\mathrm{R}$ & $\mathrm{R}$ & $\mathrm{R}$ \\
\hline control & & & & & \\
& AD-66 & $\mathrm{S}$ & $\mathrm{S}$ & $\mathrm{S}$ & $\mathrm{S}$ \\
& Bačvanin & $\mathrm{R}$ & $\mathrm{R}$ & $\mathrm{R}$ & $\mathrm{R}$ \\
\hline
\end{tabular}

(R) broomrape absent

(S) broomrape present

Table 3: Mean values of plant height, head diameter, seed oil content of new broomraperesistant $R f$ lines developed in 2004 from interspecific populations originating from H. deserticola

\begin{tabular}{llccc}
\hline \multirow{2}{*}{ Population } & \multirow{2}{*}{ Rf } & \multicolumn{3}{c}{2004} \\
\cline { 3 - 5 } & & $\mathrm{PH}$ & $\mathrm{HD}$ & $\mathrm{SOC}$ \\
\cline { 3 - 5 } & & 148 & $\mathrm{~cm}$ & $\%$ \\
\hline DES-1474-1 & RHA-D-2 & 165 & 13.5 & 47.2 \\
DES-1474-1 & RHA-D-5 & 134 & 13.0 & 49.3 \\
DES-1474-1 & RHA-D-6 & 143 & 12.7 & 40.6 \\
DES-1474-1 & RHA-D-7 & 173 & 14.0 & 49.0 \\
DES-1474-1 & RHA-D-8 & 1.69 & 2.23 & 48.1 \\
\hline & LSD 0.05 & 2.48 & 3.50 & 4.06 \\
& LSD 0.01 & & & 5.14 \\
\hline
\end{tabular}

$R f$ - restorer inbred line; $\mathrm{PH}$ - plant height

$\mathrm{HD}$ - head diameter; SOC - oil content

The 15 experimental hybrids were made by crossing new $R f$ lines to three female cms lines. The broomrape resistance of the new experimental hybrids was assessed in a location in Serbia (Pačir) during three years $(2006,2007,2008)$, using two controls: the hybrid Bačvanin, resistant to broomrape race $\mathrm{E}$, and line AD66 susceptible to all broomrape races. As race F is present in Romania, the resistance of the same hybrids was also tested and confirmed there, in the location Baragan, Braila, in 2008 (Table 4).

The new experimental hybrids resistant to broomrape differed significantly among themselves in plant height $(170-210 \mathrm{~cm})$, head diameter $(20-24 \mathrm{~cm})$, seed yield (2.60-4.88 t/ha), seed oil content (46.5-52.0\%) and oil yield (1.27-2.42 t/ha). Regarding the most important agronomic traits such as seed (SY) and oil yield (OY), three resistant hybrids were significantly better than all three standard hybrids: Ha- 
Table 4: Results of field testing of NS sunflower hybrids grown in broomrape-infected plots in Pačir (2006-2008) and Braila (2008)

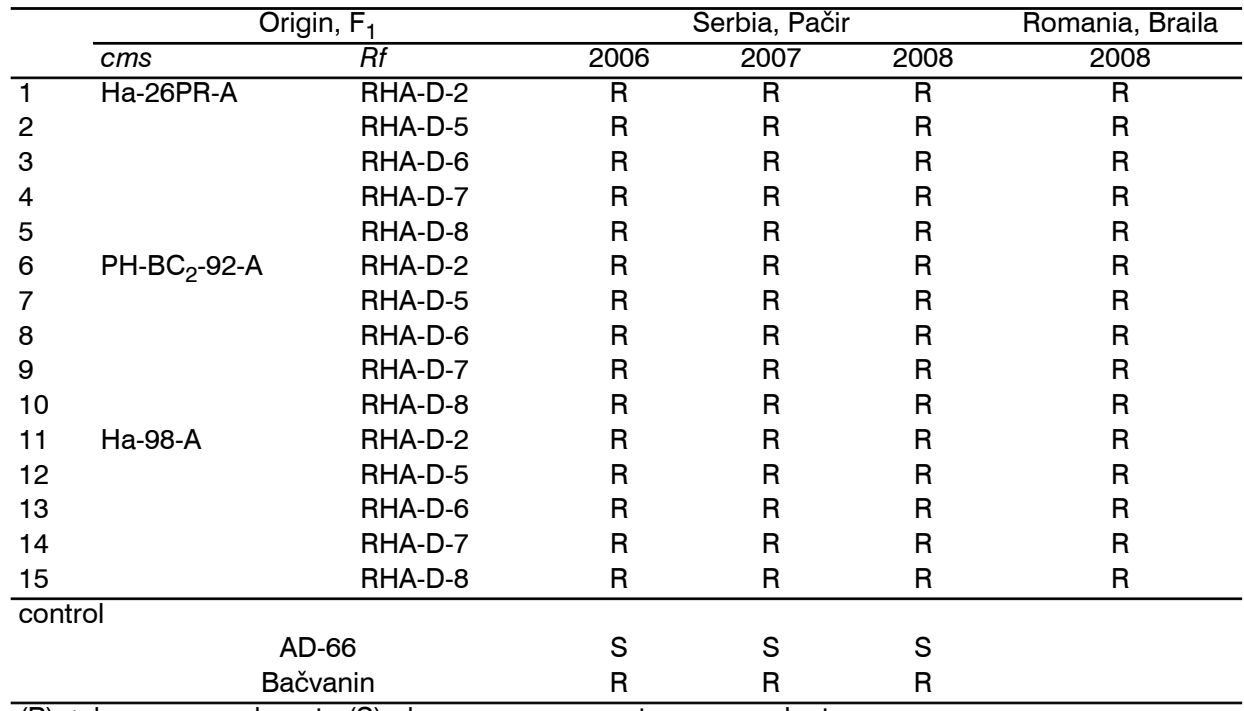

(R) + broomrape absent; (S) - broomrape present on every plant

Table 5: Characteristics of the 15 experimental hybrids resistant to broomrape tested in 2007 in the location of Srbobran

\begin{tabular}{|c|c|c|c|c|c|c|}
\hline \multicolumn{2}{|r|}{ Hybrid } & $\mathrm{PH}$ & $\mathrm{HD}$ & SY & SOC & OY \\
\hline \multirow{2}{*}{$\begin{array}{l}\text { Female } \\
\text { Ha-26PR-A }\end{array}$} & male & $\mathrm{cm}$ & $\mathrm{cm}$ & t/ha & $\%$ & t/ha \\
\hline & RHA-D-2 & 182 & 20.5 & 3.52 & 46.9 & 1.65 \\
\hline \multirow{4}{*}{ Ha-26PR-A } & RHA-D-5 & 200 & 20.5 & 4.82 & 49.7 & 2.37 \\
\hline & RHA-D-6 & 176 & 21.0 & 4.86 & 48.8 & 2.38 \\
\hline & RHA-D-7 & 174 & 22.0 & 3.80 & 48.7 & 1.85 \\
\hline & RHA-D-8 & 210 & 23.0 & 4.88 & 49.6 & 2.42 \\
\hline \multirow[t]{5}{*}{${\mathrm{PH}-\mathrm{BC}_{2}-\mathrm{-92-A}}^{-\mathrm{A}}$} & RHA-D-2 & 180 & 20.0 & 3.34 & 49.5 & 1.66 \\
\hline & RHA-D-5 & 190 & 21.0 & 2.95 & 48.5 & 1.43 \\
\hline & RHA-D-6 & 188 & 20.0 & 2.90 & 46.5 & 1.35 \\
\hline & RHA-D-7 & 170 & 23.1 & 2.60 & 49.2 & 1.27 \\
\hline & RHA-D-8 & 205 & 21.0 & 3.35 & 49.3 & 1.65 \\
\hline \multirow[t]{5}{*}{ Ha-98-A } & RHA-D-2 & 190 & 22.0 & 3.90 & 52.0 & 2.03 \\
\hline & RHA-D-5 & 198 & 22.0 & 3.98 & 49.8 & 1.98 \\
\hline & RHA-D-6 & 196 & 22.0 & 3.95 & 49.8 & 1.97 \\
\hline & RHA-D-7 & 194 & 24.0 & 3.95 & 50.0 & 1.89 \\
\hline & RHA-D-8 & 201 & 24.0 & 3.95 & 49.8 & 1.97 \\
\hline \multicolumn{7}{|l|}{ standard } \\
\hline \multirow{2}{*}{\multicolumn{2}{|c|}{$\begin{array}{l}\text { NS-H-111 } \\
\text { Perun }\end{array}$}} & 175 & 21.0 & 4.54 & 48.9 & 2.22 \\
\hline & & 155 & 22.0 & 3.77 & 47.6 & 1.79 \\
\hline \multicolumn{2}{|c|}{ Pobednik } & 160 & 21.0 & 3.87 & 50.7 & 1.96 \\
\hline \multicolumn{7}{|l|}{ control } \\
\hline \multicolumn{2}{|c|}{ LSD 0.05} & 3.52 & 1.67 & $\begin{array}{l}0.29 \\
0.29\end{array}$ & 1.26 & 0.143 \\
\hline \multicolumn{2}{|c|}{ LSD 0.01} & 4.71 & 2.24 & 0.39 & 1.69 & 0.191 \\
\hline
\end{tabular}

PH - plant height; HD - head diameter; SY - seed yield; SOC - oil content; OY - oil yield 
26-PR $\times$ RHA-D8 (SY 4.88t/ha; OY 2.42t/ha), Ha-26-PR $\times$ RHA-D6 (SY 4.86t/ha; OY 2.38 t/ha), Ha-26-PR $\times$ RHA-D5 (SY 4.82t/ha; OY 2.37t/ha) (Table 5).

New sources of resistance to broomrape have have extensvely been searched for in wild species, with focus on $H$. tuberosus (Jan et al., 2002). Most of the NS hybrids resistant to broomrape produced so far have been based on interspecific populations with $H$. tuberosus, among them being the hybrid Bačvanin, used as a standard in our investigation (Škorić and Jocić, 2005). Results on the resistance in other wild sunflower populations are scarce. Seiler (1994) reported that interspecific lines derived from $H$. anomalus, $H$. argophillus and $H$. deserticola displayed some level of resistance against broomrape race SE-192. Ruso et al. (1996) declared only three interspecific populations, ANO-1509-2-2, ARG-420-1-2 and DES-1474-1-2, derived from $H$. anomalus, $H$. argophillus and $H$. Deserticola, respectively, as partially resistant to broomrape race SE-193. It is known that each wild species has a great variability among its populations, which mutually differ in values of the majority of qualities and traits (Seiler and Gulya, 2004).

Here we showed that $R f$ inbred lines developed from interspecific population with $H$. deserticola - DES-1474-1, are resistant to broomrape race E and possibly race $\mathrm{F}$, and indicated that this population can be used for the production of new resistant sunflower hybrids.

\section{CONCLUSION}

Fifteen new experimental hybrids were made by crossing female inbred lines susceptible to broomrape race $\mathrm{E}$ with new $R f$ inbred lines, developed from the interspecific population DES-1474-1, originating from $H$. deserticola and resistant to broomrape race E. All the examined hybrids were resistant to broomrape in locations infected with race $\mathrm{E}$. Since broomrape race $\mathrm{F}$ is present in the test location in Romania, it is expected that the new $R f$ inbred lines - male components of the examined hybrids - possess the resistance gene for race $\mathrm{F}$ too. Our results indicate that the interspecific population DES-1474-1 can be used for the production of new sunflower hybrids resistant to broomrape.

\section{REFERENCES}

Dominguez J., Melero-Vara J.M. and Refoyo A., 1996. Virulence groups of Orobanche cernua in Andalusia (southern Spain). In: Moreno, M., Cubero, J., Berner, D., Joel, D., Musselman, L. and Parker, C. [Eds.]. Adv. Parasitic Plant Res. Proc. $6^{\text {th }}$ Int. Symp. in Parasitic Weed, Cordoba, Spain, Congresos y Jornadas 36/96. Direccion General de Investigacion Agraria, Consejeria de Agricultura y Pesca, Sevilla, Spain, pp. 633-637.

Fernandez-Martinez, J.M., Dominguez, J., Perez-Vich, B. and Velasco, L., 2008. Update on breeding for resistance to sunflower broomrape. Helia 31(48): 73-84.

Jan, C.C., Fernandez-Martinez, J.M., Ruso, J. and Munoz-Ruz, J., 2002. Registration of four sunflower germplasms with resistance to Orobanche cumana race F. Crop Sci. 42: 22172218.

Kaya, Y., Demerci, M., Evci, G., 2004. Sunflower (Helianthus annuus L.) breeding in Turkey for broomrape (Orobanche cernua Loeffl.) and herbicide resistance. Helia 27(40): 199210. 
Mihaljčević, M., 1994. Broomrape (Orobanche cumana Wallr.) on sunflower in Vojvodina. Periodical of Scientific Res. on Field and Vegetable Crops, Novi Sad 25: 59-71.

Ruso, J., Sukno, S., Dominguez-Gimenez, J., Melero-Vara, J.M. and Fernandez-Martinez J.M., 1996. Screening of wild Helianthus species and derived lines for resistance to several populations of Orobanche cernua. Plant Dis. 80: 1165-1169.

Seiler, G.J., 1992. Utilization of wild sunflower species for the improvement of cultivated sunflower. Field Crops Res. 30: 195-230.

Seiler, G.J., 1994. Oil concentration and fatty acid composition of achenes of North American Helianthus (Asteraceae) species. Econ. Bot. 48: 276-279.

Seiler, G.J. and Gulya, T.J., 2004. Exploration for wild Helianthus species in North America: Challenges and opportunities in the search for global treasures. Proc. $16^{\text {th }}$ Int. Sunf. Conf., Fargo, ND 1: 43-68.

Seiler, G.J. and Rieseberg, L.H., 1997. Systematics, origin. and germplasm resources of wild and domesticated sunflower. In: Schneiter, A.A., [ed.], Sunflower Technology and Production. Crop Science Society of America, Madison, WI., USA, pp. 21-65.

Seiler, G.J. and Brothers, M.E., 2003. Exploration for wild Helianthus anomalus and $H$. deserticola in the desert Southwest. USA, Proc. $25^{\text {th }}$ Sunf. Res. Workshop, Fargo, ND, Nat. Sunf. Assoc., Bismarck, ND. 2003. (Available at: http://www.sunflowernsa.com/ research/research_workshop/documents/90.pdf).

Shindrova, P., Ivanov, P., Nikolova, V., 1998. Effect of broomrape (Orobanche cumana Wallr.) intensity of attack on some morphological and biochemical indices of sunflower (Helianthus annuus L.). Helia 21(29): 55-62.

Škorić, D., Jocić, S., 2005. Use of wild species in sunflower species as an alternative to genetic transformations. J. Sci. Agric. Research/Arh. polj. Nauke 66(237): 115-123.

Škorić, D., Jocić, S., Hladni N., Vannozzi, G.P., 2007. An analysis of heterotic potential for agronomically important traits in sunflower (Helianthus annuus L.). Helia, 30(46): 5573 .

\title{
EL USO DE NUEVAS LÍNEAS ENDOCRIADAS RF ORIGINADAS DE UNA POBLACIÓN INTERESPECÍFICA CON H. deserticola PARA LA PRODUCCIÓN DE HÍBRIDOS RESISTENTES AL JOPO
}

\author{
RESUMEN
}

Uno de los objetivos de mejoramiento de girasol es la selección por la resistencia al jopo. La población de jopo se ha mantenido estable en Serbia durante un largo período de tiempo, pero la composición racial ha cambiado últimamente, con la raza $\mathrm{E}$ predominando en las regiones del norte de $\mathrm{Ba}$ ?ka y Banat. El girasol cultivado es genéticamente estrecho y deficiente en varios genes deseables. Su variabilidad genética puede ser incrementada mediante el uso de especies silvestres de girasol e hibridación interespecífica. La resistencia de 15 nuevos híbridos experimentales al jopo se probó en localidades de Serbia (Pačir), durante tres años (2006, 2007 y 2008), y en Rumania (Baragan, Braila), durante el 2008. Estos híbridos se produjeron cruzando líneas hembras endocriadas (Ha-26PR-A, $\mathrm{PH}-\mathrm{BC}_{2}-92-\mathrm{A}$ y Ha-98-A), susceptibles a la raza E del jopo, y nuevas líneas endocriadas $R f$ (RHA-D-2, RHA-D-5, RHA-D-6, RHA-D-7, RHA-D-8), desarrolladas a partir de poblaciones interespecíficas originadas de $H$. deserticota, resistentes a la raza $\mathrm{E}$ del jopo. En ambas localidades, todos los híbridos examinados fueron resistentes al jopo. Visto que la raza $\mathrm{F}$ del jopo está presente en esa localidad rumana, se espera que los componentes masculinos de las nuevas líneas endocriadas $R f$ los de híbridos examinados, posean también el gen de resistencia para la raza $\mathrm{F}$. 


\title{
L'UTILISATION DE NOUVELLES LIGNÉES PURES $R f$ ISSUES DE LA POPULATION INTERSPÉCIFIQUE $H$. deserticola EN VUE DE LA PRODUCTION DES HYBRIDES DE TOURNESOL RÉSISTANTS À l'Orobanche
}

\author{
RESUME
}

L'un des objectifs majeurs dans la sélection du tournesol est la résistance à l'Orobanche. La population de ce parasite en Serbie est restée stable pendant une longue période, mais la composition des souches a changé ces dernières années avec la race $\mathrm{E}$ prédominante dans les régions nord de Bačka et de Banat.

Le tournesol cultivé est génétiquement déficient pour de nombreux gènes complémentaires. Sa variabilité génétique peut être améliorée en utilisant des espèces sauvages de tournesol et l'hybridation interspécifique.

La résistance à l'Orobanche de 15 nouveaux hybrides expérimentaux a été étudiée en Serbie (Pačir) durant trois ans (2006, 2007 et 2008) et en Roumanie (Baragan, Braila) en 2008.

Ces hybrides ont été produits en croisant des lignées femelles (HA-26 PR$\mathrm{A}, \mathrm{PH}-\mathrm{BC}_{2}$-92-A et HA-98-A) sensibles à la race $\mathrm{E}$ d'Orobanche et de nouvelles souches mâles restorer $R f$ (RHA-D-2, RHA-D-5, RHA-D-6, RHA-D-7, RHA-D-8), développées à partir de populations interspécifiques dérivant de Helianthus deserticola et résistantes à la race $\mathrm{E}$.

Tous les hybrides examinés dans ces deux endroits étaient résistants à l'Orobanche. La race $\mathrm{F}$ d'Orobanche étant présente en Roumanie, il est espéré que les nouvelles lignées $R f$ - parents mâles des hybrides étudiés, possèdent également le gène de résistance pour la race $\mathrm{F}$. 